\title{
Species Richness Pattern along Altitudinal Gradient in Central European Beech Forests
}

\author{
Richard Hrivnák • Dušan Gömöry • Michal Slezák • \\ Karol Ujházy • Radim Hédl • Benjamín Jarčuška • \\ Mariana Ujházyová
}

(C) Institute of Botany, Academy of Sciences of the Czech Republic 2013

\begin{abstract}
The unimodal species richness-altitude distribution pattern seems to be universal. To investigate the validity of this phenomenon in homogeneous substrate and vegetation conditions, we sampled beech-dominated forests in five volcanic mountain ranges in the Western Carpathians. European beech (Fagus sylvatica L.) formed monodominant closed-canopy stands at altitudes from 300 to $1,200 \mathrm{~m}$. Along this gradient, the influence of beech on understory plant species richness was expected to be strong and uniform. The shape of the species richness-altitude relationship was analyzed for three datasets: herb layer, shrub layer, and both layers merged together. Contrary to prediction, the studied species richness-altitude relationship was inversely unimodal, with a minimum at intermediate altitudes. Quadratic regression models were statistically significant for all three datasets $(P<0.001)$ and the explained variability ranged from $12 \%$ to $20 \%$. The possible explanation for the observed pattern is twofold.
\end{abstract}

R. Hrivnák $(\bowtie) \cdot$ M. Slezák

Institute of Botany, Slovak Academy of Sciences, Dúbravská cesta 9, SK-845 23 Bratislava, Slovakia e-mail: richard.hrivnak@savba.sk

D. Gömöry • K. Ujházy

Department of Phytology, Faculty of Forestry, Technical University, T. G. Masaryka 24,

SK-960 53 Zvolen, Slovakia

M. Slezák

Department of Biology and Ecology, Faculty of Education, Catholic University, Hrabovská cesta 1, SK-034 01 Ružomberok, Slovakia

R. Hédl

Institute of Botany, Academy of Sciences of Czech Republic, Lidická 25/27, CZ-602 00 Brno, Czech Republic

B. Jarčuška

Institute of Forest Ecology, Slovak Academy of Sciences, L'. Štúra 2, SK-960 53 Zvolen, Slovakia

M. Ujházyová

Department of Applied Ecology, Faculty of Ecology and Environmental Sciences, T. G. Masaryka 24, SK-960 53 Zvolen, Slovakia 
In the central part of the altitudinal gradient, low species richness is due to strong competition by monodominant beech with accumulation of leaf litter and uptake soil resources, mainly water. This influence is somewhat released towards the margins of the gradient. Secondly, the species pool from the neighbouring communities increases species richness only in the lower parts of the altitudinal gradient.

Keywords Altitude $\cdot$ Beech-dominated forests $\cdot$ Competition $\cdot$ Species pool $\cdot$ Species richness

Plant and communities' nomenclature Marhold and Hindák (1998) for plants, Jarolímek and Šibík (2008) for plant communities

\section{Introduction}

It has been observed that patterns of species diversity are associated with altitudinal gradients. A simple rule says that the species richness-altitude relationship follows the same principle as the analogous latitudinal pattern (Stevens 1992; Colwell and Hurtt 1994). Species richness of various taxonomic groups decreases towards the poles or high altitudes (Adams 2009). However, the altitudinal relationship is clearly a more complex and often misinterpreted phenomenon (Rahbek 1995, 2005). Vascular plant diversity in vegetation plots typically shows a unimodal altitudinal pattern, with maxima at intermediate altitudes (Minchin 1989; Bhattarai and Vetaas 2003; Grytnes 2003; Grytnes et al. 2006; Grau et al. 2007). Most such studies reviewed by McCain and Grytnes (2010) revealed this trend, therefore the unimodal species richness-altitude patterns may seem to be universal. Departures from the general rule can be accounted for by their restricted altitudinal gradients with missing samples from low altitudes (Rahbek 2005), interference of various environmental factors following the altitudinal gradient (Bhattarai and Vetaas 2006; Brehm et al. 2007) and due to scale - size of sampling units and geographical range of sampling (Shmida and Wilson 1985; Rahbek 1995; Chase and Leibold 2002; Grytnes et al. 2008). Definition of the response group can also matter: analyzing the relationship for species functional groups, the prevailing unimodal relationship can turn into reversely unimodal (with minima at the mid-altitudes) or increasing linear relationships, as Kessler (2000) observed in epiphytic subgroups of the main taxonomic groups and endemic taxa among the epiphytes, respectively.

Altitude is not an ecological factor per se. Two types of factors are thought to shape the diversity patterns on altitudinal gradients: environmental (or biological, Shmida and Wilson 1985), and stochastic (or non-biological, Colwell and Hurtt 1994). Altitude is a surrogate for several, often co-varying gradients (Rahbek 2005). The most important environmental factors are temperature, precipitation and solar radiation (Leathwick et al. 1998; Larcher 2003). At high altitudes, factors such as snow and ice formations can be limiting for plants (Körner 1999). On the other hand, altitude can imply increased precipitation in arid environments, thus increasing species richness-altitude relationships at the local (Sanders et al. 2003) and regional scales (Lobo et al. 2001). Altitudinal gradient can be combined with other independent environmental gradients further contributing to the complexity of the richness-altitude relationship (Minchin 1989; 
Oommen and Shanker 2005). For example, the mid-domain effect is a major stochastic cause of unimodal diversity patterns (Colwell and Lees 2000; Colwell et al. 2004).

The turnover of biotic communities constitutes a strong background for the diversityaltitudinal patterns. It is reflected in tree species composition and species pools, both affecting diversity patterns in understory species richness in forest vegetation. This influence has been often neglected, potentially confounding the observed species richness-altitude patterns. Beechwoods of the temperate regions of Central Europe provide an excellent opportunity to study the environment-vegetation patterns, because they are dominated by one tree species, thus substantially reducing the variance by dominant species. The high competitive ability of European beech (Fagus sylvatica L.) results in the development of relatively homogeneous vegetation across a wide range of habitats and environmental gradients including altitude (Härdtle et al. 2004; Ellenberg and Leuschner 2010). The species forms monodominant closed canopy stands, with the understory vegetation being composed of herb species adapted to shady conditions and the high production of slowly decomposing leaf litter (Sydes and Grime 1981; Ellenberg and Leuschner 2010). The most important drivers of herb layer species diversity are light availability, soil productivity-related variables (Härdtle et al. 2004; Willner et al. 2004; Kooijman and Cammeraat 2010) and the disturbance-management regime (Schmidt 2005, but see Graae and Heskjær 1997). However, no significant correlation between species richness and altitude has been found in beech forests across Central Europe (Willner et al. 2004), which may be due to the prevailing effects of soil reaction and light on plant species diversity.

To minimize the influence of confounding factors on the species richness-altitude relationship, we restricted our dataset to beech-dominated forests on volcanic bedrock, choosing five neighbouring mountain ranges in the Western Carpathians. Species composition was sampled using plots distributed at altitudes ranging over $900 \mathrm{~m}$, which is nearly the entire altitudinal range of the beech-dominated forests in the region. Because the unimodal pattern seems to be typical for studies covering complete altitudinal gradients of vegetation (from plants, as such, up to particular vegetation types; e.g. Bruun et al. 2006; Brinkmann et al. 2009; McCain and Grytnes 2010), and our material covered the whole gradient of beech-dominated forests in the area of interest, we expected to find a unimodal species richness-altitude relationship as well. Our aim was to describe and examine the species richness-altitude relationship and to identify the main drivers of this pattern.

\section{Material and Methods}

\section{Study Area}

The species richness of beech forest vegetation was studied in five volcanic mountain ranges in the Western Carpathians in southern Slovakia. They were the Cerová vrchovina Mts, Ostrôžky Mts, Javorie Mts, Štiavnické vrchy Mts and Pol'ana Mts $\left(48.16^{\circ}-48.67^{\circ} \mathrm{N}\right.$, $18.75^{\circ}-19.99^{\circ} \mathrm{E}$; see Fig. 1). The altitudes of the vegetation plots ranged from 307 to 1,190 $\mathrm{m}$ a.s.l., the lowest plot being located in the Javorie Mts and the highest in the Pol'ana Mts (Table 1). The influence of the Pannonian climate - with warmer, drier and longer vegetation seasons - is recognizable in the southern part of the study area, whereas the cooler and more humid Carpathian climate affects its northern part. This latitudinal 


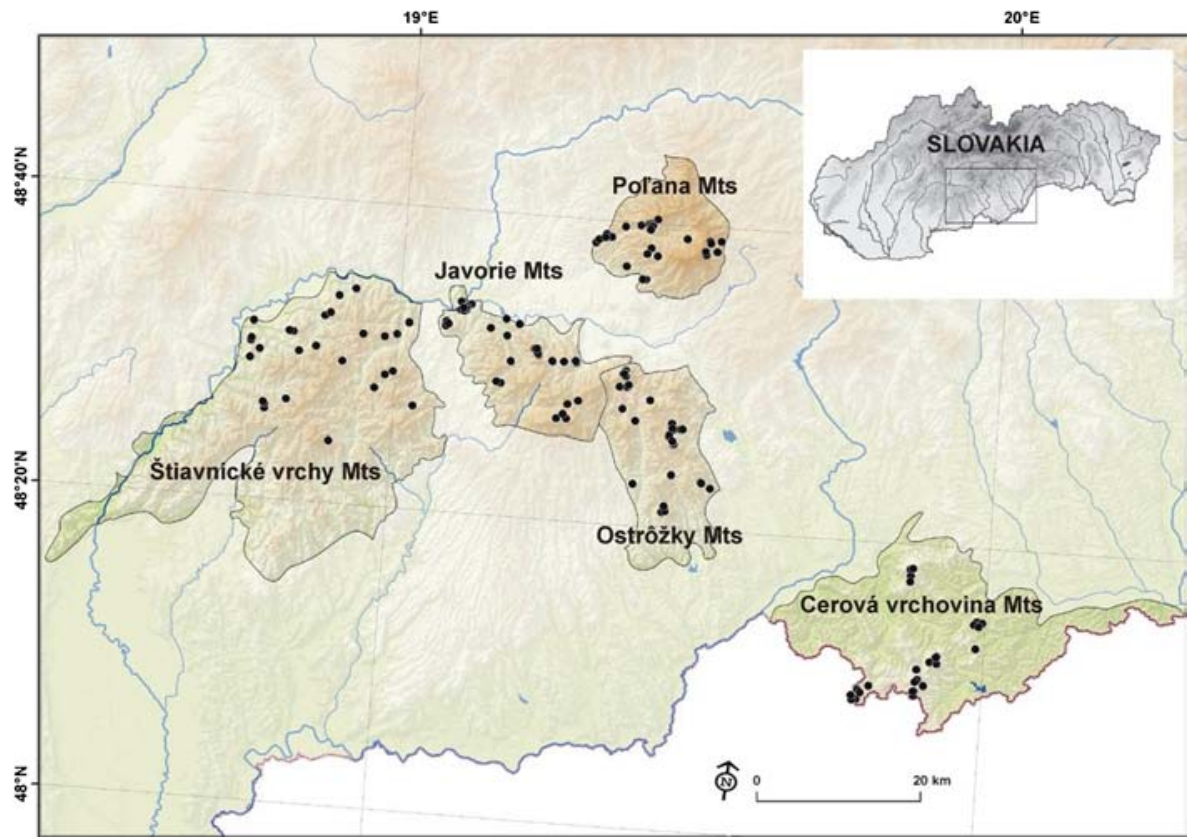

Fig. 1 Map of the studied area with the five mountain ranges sampled for beech-dominated forests. Black points represent sampling plots

climatic gradient partially overlaps with the gradient of altitude. The studied mountain ranges are similar to each other concerning relief forms and volcanic bedrock.

Beech forest vegetation is bordered at its lower end of the altitudinal gradient predominately by oak-hornbeam forests, which is particularly the situation in the south-situated ranges (Cerová vrchovina, Ostrôžky and Štiavnické vrchy Mts). Beech forests are dominant in the Javorie Mts and oak-hornbeam forests are frequent there as well. Mountain fir-beech forests prevail in the Pol'ana Mts, silver fir (Abies alba) and sycamore maple (Acer pseudoplatanus) represent the most common admixed overstory species. Norway spruce (Picea abies) is admixed at the highest altitudes in the contact zone with natural spruce forests.

\section{Sampling and Dataset}

The dataset consisting of 168 plots (Table 1 and Fig. 1) was obtained between 1994 and 2009. In each plot, species composition was recorded using the Braun-Blanquet approach (Mueller-Dombois and Ellenberg 1974). The plots were placed subjectively during field sampling in sites with mature closed-canopy forest stands (total cover of tree layer $>65 \%$ ) dominated with Fagus sylvatica (cover over $50 \%$ ). Plots were distributed regularly along the whole altitudinal gradient in each mountain range for the area of beechwoods occupying altitudinal zones. Before data analysis, species taxonomy and nomenclature were standardized using the concept of broadly defined taxa according to Marhold and Hindák (1998): Crataegus sp. (C. monogyna, C. laevigata, C. species), Dryopteris carthusiana agg. (D. carthusiana, D. dilatata), Galeopsis sp. (G. species, 


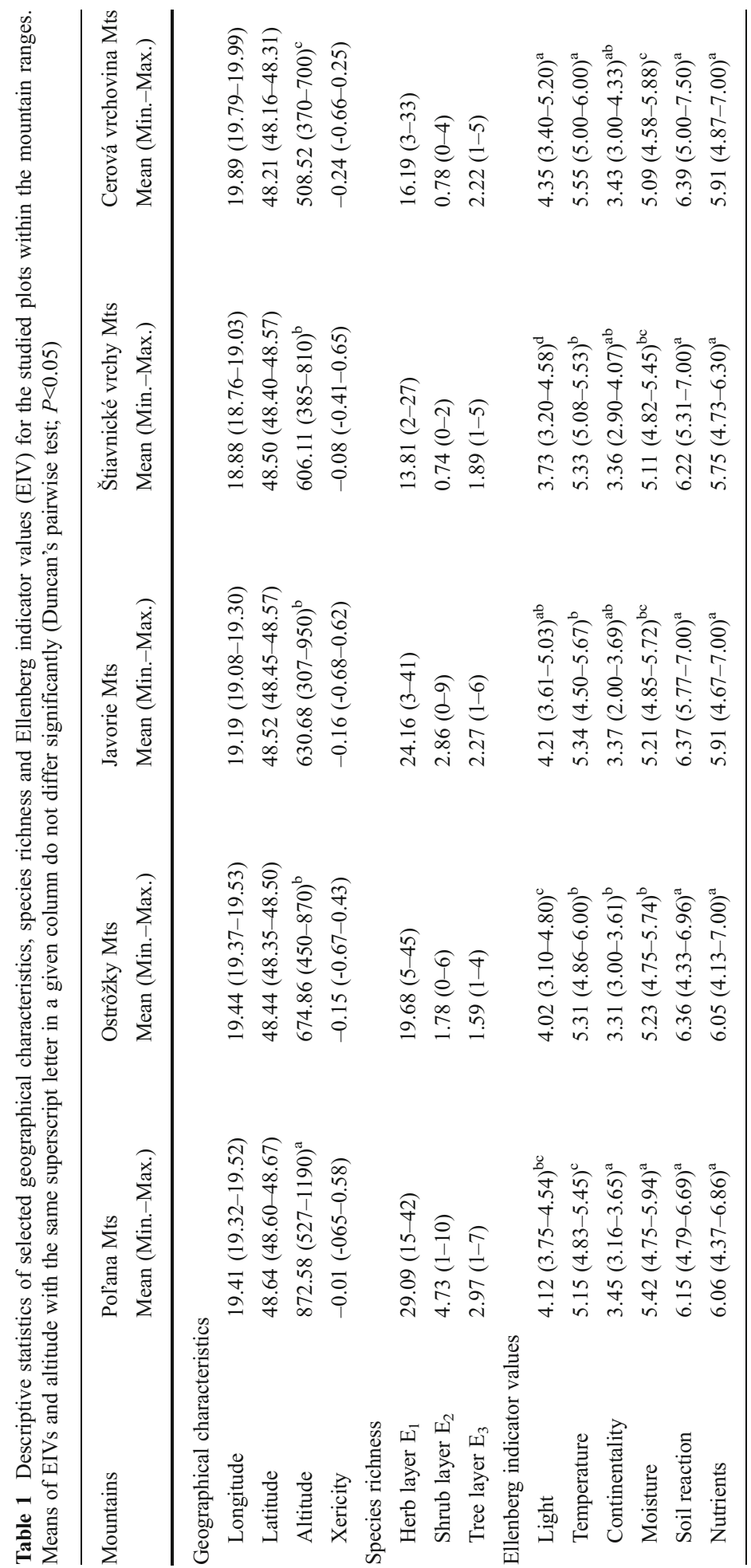


G. speciosa, G. tetrahit), Glechoma hederacea agg. (G. hederacea, G. hirsuta), Quercus petraea agg. (Q. dalechampii, Q. petraea, Q. polycarpa), Senecio nemorensis agg. (S. ovatus, S. germanicus, $S$. nemorensis), Viola hirta agg. (V. collina, V. hirta).

\section{Data Analyses}

Species richness was calculated for $i$ ) the herb $\left(E_{1}\right)$ and shrub $\left(E_{2}\right)$ layer separately (Mueller-Dombois and Ellenberg 1974), and ii) understory vegetation (UV), merging herb $\left(E_{1}\right)$ and shrub $\left(E_{2}\right)$ layers while excluding tree species juveniles. Non-weighted Ellenberg indicator values of vascular plants (EIV; Ellenberg et al. 1992) were calculated for all relevés using the Juice software (Tichý 2002). The overall purpose of the analyses was to make a comparison of ecological conditions among the five mountain ranges included in this study, as well as seek an explanation of the mechanisms underlying the species richness-altitude relationship. Differences in EIV, altitude and species richness of individual layers among the mountain ranges were tested by analyses of variance. Pairwise differences were tested by Duncan's test (procedure GLM; SAS 2009). EIVs were also regressed against altitude (linear and quadratic regression) to identify what environmental factors underlie the altitudinal gradient.

We tested the effects of altitude, orographical unit and environmental covariates (see below) on species richness by analysis of covariance. As orographical unit was considered a random-effect factor, we used a mixed model where parameters were modelled using the restricted maximum likelihood approach (procedure MIXED; SAS 2009; data not shown). Both the effect of orographical unit and unit $\times$ altitude interaction were statistically significant $(P<0.05)$; however, the effects of both the linear and quadratic terms of the species richness-altitude relationship were non-significant in all three cases $\left(E_{1}, E_{2}, U V\right)$. We then tested the elevational trends of species richness separately by mountain range. Except for the Javorie Mts, where an inverse unimodal trend was revealed, no significant regression models were found: a result that can be attributed to the fact that only in the Javorie Mts is the altitudinal range big enough to cover a substantial part of the total altitudinal gradient (data not shown). However, as all orographical units are homogeneous with respect to the above-mentioned environmental characteristics (EIV), we considered it acceptable to pool the data from all those orographical units which cover overlapping but different parts of the altitudinal gradient, and treat them as a single dataset.

The varying relevé area $\left(300-540 \mathrm{~m}^{2}\right)$ was significantly positively correlated with species richness within the shrub layer $(r=0.15 P=0.045)$, while the correlation was not significant within the herb layer $(r=0.03, P=0.672)$ and $\mathrm{UV}(r=0.03, P=0.696)$. To allow for direct comparison for both layers, the relevé size was included in the regression models as a covariate. To account for the effects of aspect and slope which may be confounded with the effects of altitude, we calculated a xericity index from slope and aspect (Austin et al. 1984), and included it into the regression models as a covariate. Similarly, cover of the tree layer was included into regression models as a covariate, because this characteristic had a relatively wider variability and could affect the outcomes of the analyses. We used both linear and quadratic regression for the identification of species richness trends along the altitudinal gradient. The appropriate regression model was selected based on adjusted $R^{2}$ and the significance of the regression coefficient of the quadratic term $\left(\mathrm{H}_{0}: \beta_{2}=0\right)$. In cases where inversely unimodal models proved to be 
significant, the minima of the regression curves were derived by setting the first derivative of the regression function equal to zero and solving the resulting equation for altitude. Calculations were done using the procedure REG of SAS (SAS 2009).

Ordination analysis (detrended correspondence analysis, DCA) using CANOCO for Windows (ter Braak and Šmilauer 2002) was run to explain the species composition pattern along the altitudinal gradient. Subsequently, altitude was displayed as a categorical variable in the ordination diagram, defined in three categories: plots in $<500 \mathrm{~m}$ a.s.l., 500-900 m a.s.1. and $>900 \mathrm{~m}$ a.s.1. The altitudinal range of 500-900 m represents the optimum of European beech in the Western Carpathians (Michalko et al. 1987). Species were categorized in accord with their affinity to $i$ ) oak and oak-hornbeam forests, $i$ ) beech forests, and iii) fir-beech, beech-fir-spruce and spruce forests, following phytosociological alliances according to Jarolímek and Šibík (2008).

Venn diagrams were applied to reveal trends in the species pool partitioning among the three altitudinal categories. Firstly, the species pool of the initial dataset for assessing the altitudinal pattern of vascular plants species richness in beech-dominated forests was analyzed (168 phytosociological relevés); secondly, to find the species pool of adjacent belts, the enlarged dataset about sampling plots covering all natural forest vegetation types in particular mountain ranges was used (totally 198 relevés).

\section{Results}

The species richness-altitude relationship proved to be inversely unimodal, with a minimum at intermediate altitudes. The margins of the altitudinal gradient were characterized by increased species richness, which was more pronounced in the upper elevations. The altitudes where species richness reached minimum were $576 \mathrm{~m}, 629$ $\mathrm{m}$ and $563 \mathrm{~m}$ for herb $\left(\mathrm{E}_{1}\right)$, shrub $\left(\mathrm{E}_{2}\right)$ and combined understory (UV) layers, respectively. The quadratic terms of regression models were statistically significant for all three datasets $(P<0.001)$ with explained variability $R^{2}$ ranging from 0.12 to 0.20 (Fig. 2). Moreover, adjusted $R^{2}$ increased when quadratic terms were included in all three cases. The highest $R^{2}$ values were detected for species richness of the combined understory (UV) layer followed by herb $\left(E_{1}\right)$ and shrub $\left(E_{2}\right)$ layers. The effects of plot area, xericity and cover of tree layer did not confound the effect of altitude, all being not statistically significant $(P>0.1)$. When xericity was included as a covariate in the regression analysis, $R^{2}$ varied between 0.15 and $0.22(P<0.001$ in all cases) resulting in only a slight improvement.

The analysis by Ellenberg indicator values demonstrated that the studied mountain ranges did not significantly differ in soil nutrients (EIV-N) and soil reaction (EIV-R). However, there were differences in altitudinal ranges and the associated factors: statistically significant differences were in mean altitude and EIV for moisture (EIV-M) and temperature (EIV-T). Moreover, differences between mountain ranges were found in EIV for light (EIV-L) (Table 1).

The relationship between species composition and altitude was demonstrated in the DCA ordination diagram (Fig. 3), where the first DCA axis was closely correlated with altitude $(r=-0.723, P<0.001)$. The first two DCA axes explained $17.8 \%$ of the variance in the species data. An apparent trend from the species of the fir-beech, beech-fir-spruce and spruce forests of the montane-zone with higher precipitation (e.g. Abies alba, Oxalis 

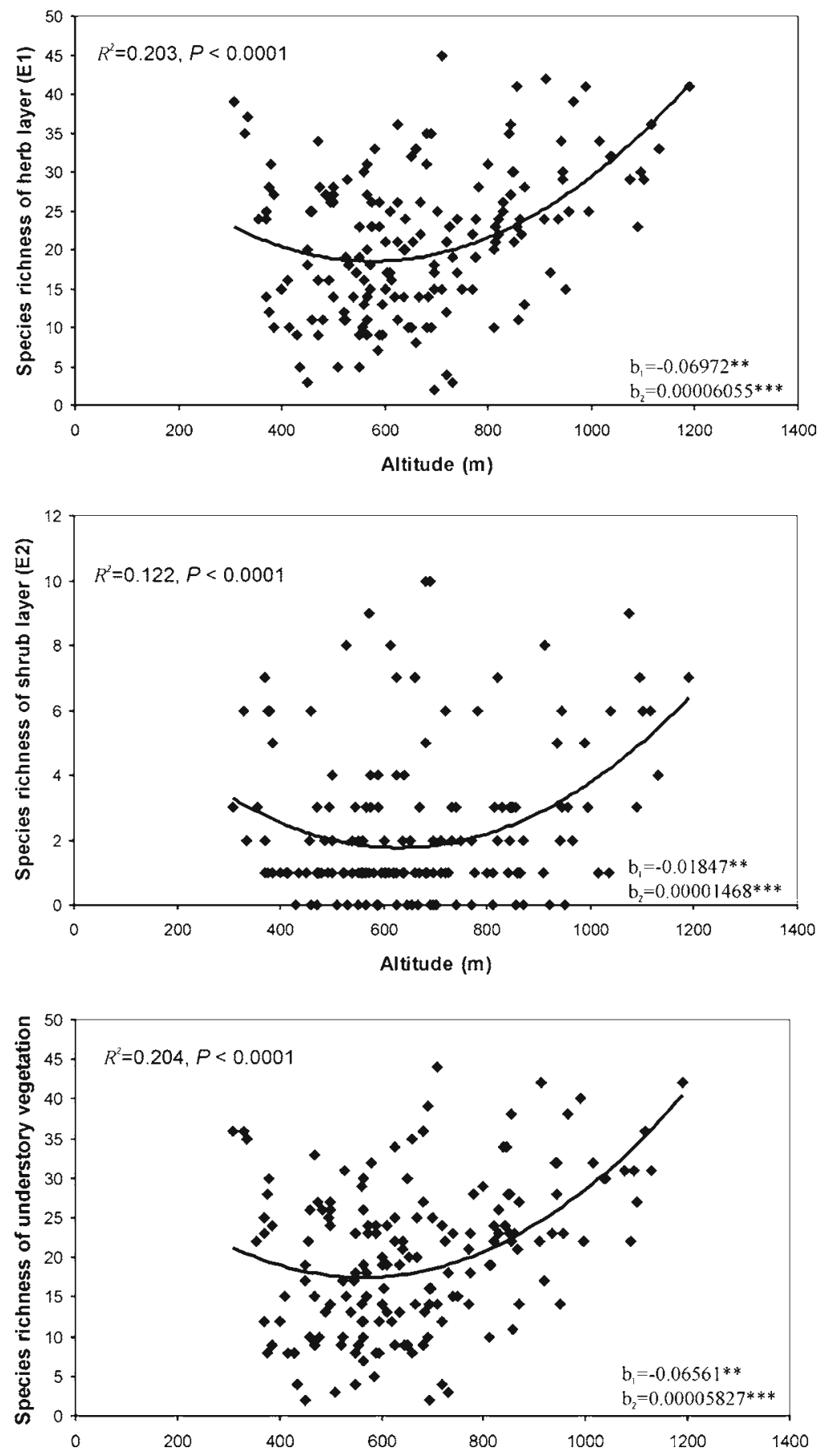

Altitude (m)

Fig. 2 Species richness distribution along the altitudinal gradient for the herb layer $\left(\mathrm{E}_{1}\right.$, above), shrub layer $\left(E_{2}\right.$, centre) and understory vegetation (UV, below), fitted to quadratic regression models; $b_{1}$ and $b_{2}$ are linear and quadratic terms of the regression model, respectively $(* *-P<0.01, * * *-P<0.001)$ 


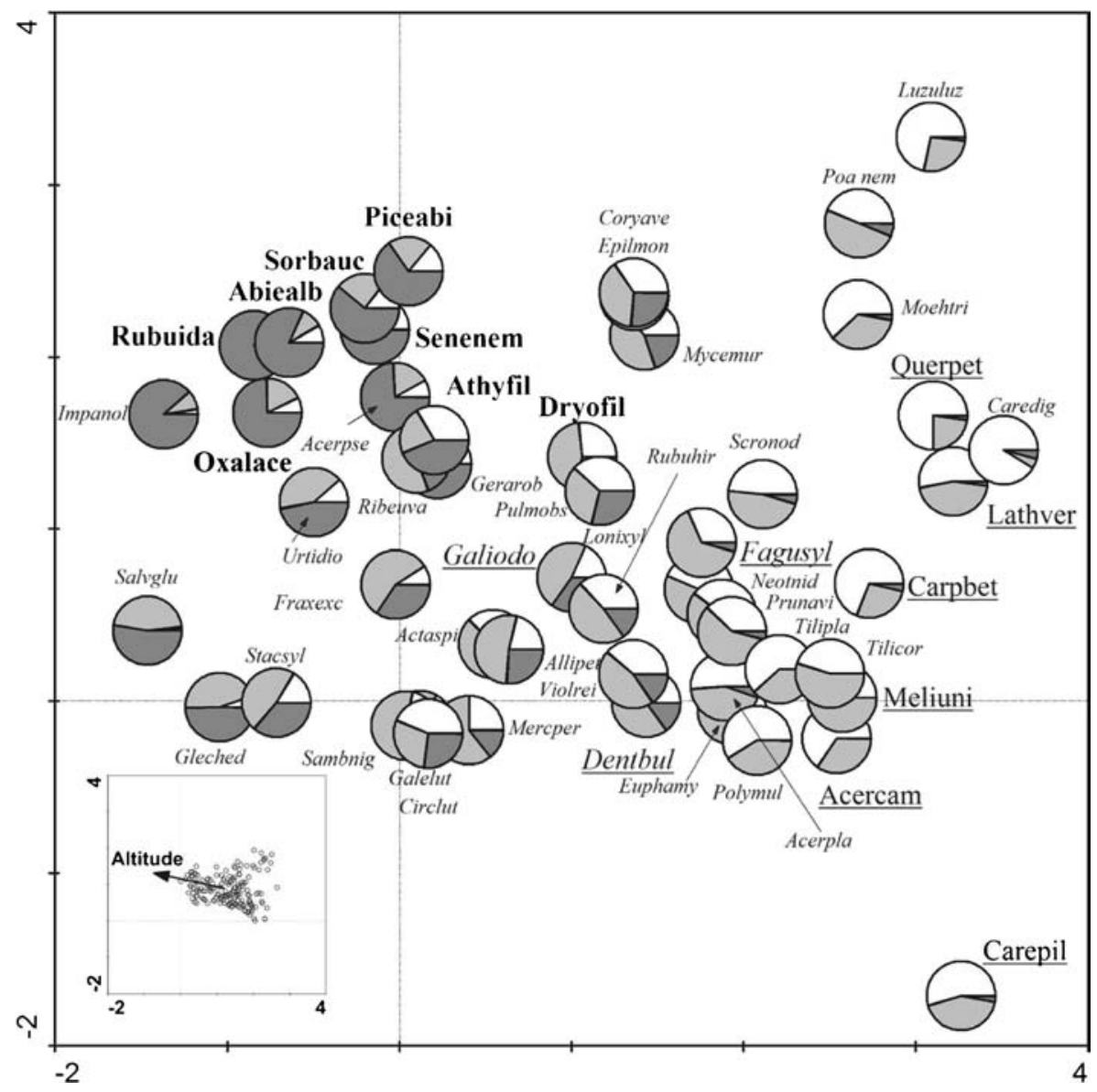

Fig. 3 Detrended correspondence analysis of species. The categories (white: $<500 \mathrm{~m}$, light grey: 500-900 $\mathrm{m}$, dark grey: $>900 \mathrm{~m}$ a.s.l.) are displayed in the ordination diagram using pie charts in the positions of particular species. Only species with a weight range of 2-100\% in the analysis are shown. Diagnostic species of oak, oak-hornbeam forests (Carpinion betuli, Quercion confertae-cerris, Quercion pubescentipetraeae, Quercion petraeae) are displayed by sole underlined script, beech forests (Fagion sylvaticae) by underlined italic script, fir-beech, beech-fir-spruce and spruce forests (Vaccinio-Picetea) are displayed by bold script and other species by sole italic script (cf. Jarolímek and Šibík 2008). The relation of the altitude gradient on sampling sites is presented in the lower part of the figure. Species names abbreviations should be read as follows: Acercam - Acer campestre, Acerpla - Acer platanoides, Acerpse - Acer pseudoplatanus, Athyfil - Athyrium filix-femina, Caredig - Carex digitata, Carepil - Carex pilosa, Carpbet - Carpinus betulus, Coryave - Corylus avellana, Dentbul - Dentaria bulbifera, Dryofil - Dryopteris filix-mas, Epilmon - Epilobium montanum, Euphamy - Tithymalus amygdaloides, Fagusyl - Fagus sylvatica, Fraxexc - Fraxinus excelsior, Galiodo - Galium odoratum, Gerarob - Geranium robertianum, Gleched - Glechoma hederacea agg., Impanol - Impatiens noli-tangere, Lathver - Lathyrus vernus, Lonixyl - Lonicera xylosteum, Luzuluz - Luzula luzuloides, Meliuni - Melica uniflora, Mercper - Mercurialis perennis, Moehtri - Moehringia trinervia, Mycemur - Mycelis muralis, Neotnid - Neottia nidus-avis, Oxalace - Oxalis acetosella, Piceabi - Picea abies, Poa nem - Poa nemoralis, Polymul - Polygonatum multiflorum, Prunavi - Cerasus avium, Pulmobs Pulmonaria obscura, Querpet - Quercus petraea agg., Ribeuva - Ribes uva-crispa, Rubuhir - Rubus hirtus, Rubuida - Rubus idaeus, Salvglu - Salvia glutinosa, Sambnig - Sambucus nigra, Scronod - Scrophularia nodosa, Senenem - Senecio nemorensis agg., Sorbauc - Sorbus aucuparia, Stacsyl - Stachys sylvatica, TilicorTilia cordata, Tilipla - Tilia platyphyllos, Urtidio - Urtica dioica, Violrei - Viola reichenbachiana 
acetosella, Picea abies) to the species of the oak and oak-hornbeam forests of the colline zone with lower precipitation (e.g. Carex pilosa, Carpinus betulus, Quercus petraea agg.) was obvious. Typical species of beech forests such as Dentaria bulbifera and Galium odoratum were positioned in the centre of the ordination diagram. Among the EIVs, only the EIV for moisture showed a statistically significant positive relationship with altitude $\left(R^{2}=0.31, P<0.0001\right.$; Fig. 4$)$. The altitudinal gradient could therefore be interpreted as a gradient of soil moisture reflected by plant species.

There was a significant positive correlation between the number of species in the tree and herb layer $(r=0.21, P=0.007)$, and the species richness of trees along the altitudinal gradient showed an inversely unimodal pattern (Fig. 5). These facts could be helpful to explain the effect of tree species composition of the canopy layer on species diversity in the understory vegetation.

Sixty-five species were common for the three altitudinal belts $(<500 \mathrm{~m}$ a.s.1., 500 $900 \mathrm{~m}$ a.s.l. and $>900 \mathrm{~m}$ a.s.1.); 34 species were present only in the $500-900 \mathrm{~m}$ belt, and 18 and 13 species were exclusive to the lower and upper altitudinal belts, respectively (Fig. 6a). Partitioning of species pools of the neighbouring communities from the species pool of beech-dominated communities of the 500-900 m belt revealed that 18 species were exclusive for this intermediate altitudinal belt. On the other hand, 102 and 31 plant species were exclusive for the lower $(<500 \mathrm{~m})$ and upper (>900 m) belts, respectively (Fig. 6b).

\section{Discussion}

\section{Species Richness-Altitudinal Gradient}

The observed inversely unimodal species richness-altitude pattern differs from the commonly reported unimodal pattern (e.g. Bruun et al. 2006; Grytnes et al. 2006; Chytrý et al. 2012). The absence of a statistically significant richness-altitude relationship reported by Willner et al. (2004) for beech forests can be explained by the evolutionary history of the studied sites (Willner et al. 2009) and by the confounding effects of soil nutrient-related parameters and light conditions. The proximity of a potential refuge area can have a pronounced effect on beech forest species richness (Willner et al. 2009). Moreover, herb layer species richness has been found to be positively correlated with light availability (Tinya et al. 2009) and soil reaction (Vockenhuber et al. 2011). We will try to explain the possible sources of these observed patterns below.

\section{Interspecific Competition by Beech}

The beech-dominated forests range from ca. 150 to $1,480 \mathrm{~m}$ a.s.l. in the Western Carpathians (Fekete and Blattny 1913; Boratyńska and Boratyński 1990; Gömöry et al. 2011), but their occurrence in the marginal parts of this gradient is only occasional. Our study was deliberately limited to volcanic mountains of central Slovakia to avoid confounding effects of bedrock and soils on vegetation. In this area, beech-dominated forests occur between 307 and 1,190 m a.s.l., which means that our study covered exhaustively the potential species altitudinal range in the study area, and a substantial 


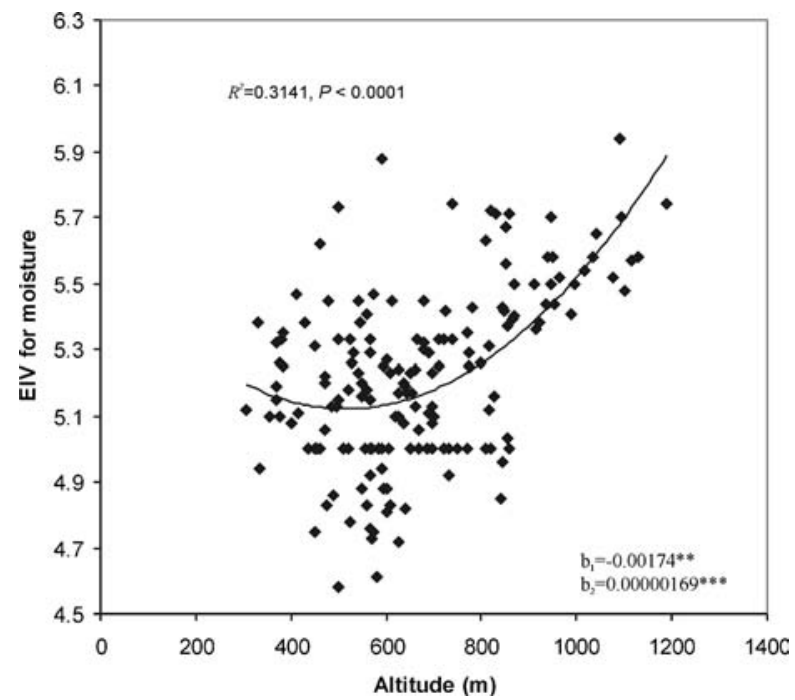

Fig. 4 Relationship between Ellenberg indicator values (EIV) for moisture (non-weighted averages in plots) and altitude; $b_{1}$ and $b_{2}$ are linear and quadratic terms of the regression model, respectively $(* *-P<0.01, * * *-P<0.001)$

part of the range for beech in the Western Carpathians. The ecological optimum of beech (indicated, for example, by the biggest biomass production) manifested by an almost absolute dominance of this tree species is located at intermediate altitudes from 500 to $900 \mathrm{~m}$ (Michalko et al. 1987). The species richness minima values observed in our study (563-621 m a.s.1.) are well within the beech optimum range. The optimal conditions for beech communities in the Western Carpathians are limited by an annual precipitation of 600-1,000 $\mathrm{mm}$ and an average annual temperature of 4- $8^{\circ} \mathrm{C}$ (Dzwonko 1990; Gömöry et al. 2011). These conditions support the high competitive ability of Fagus sylvatica, which subsequently inhibits the regeneration and growth of other tree species and suppresses the development of a forest understory.

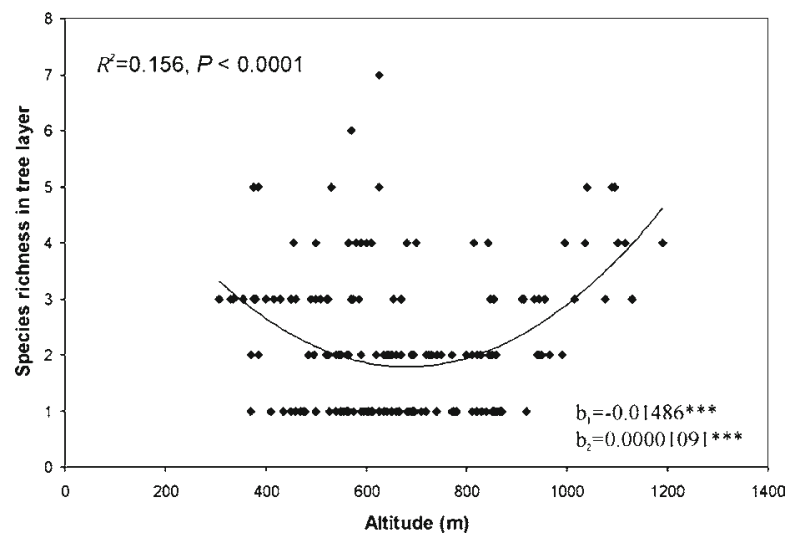

Fig. 5 Species richness of the tree layer along the altitudinal gradient; $b_{1}$ and $b_{2}$ are linear and quadratic terms of the regression model, respectively $(* *-P<0.01, * * *-P<0.001)$ 
a

Total species pool: 199

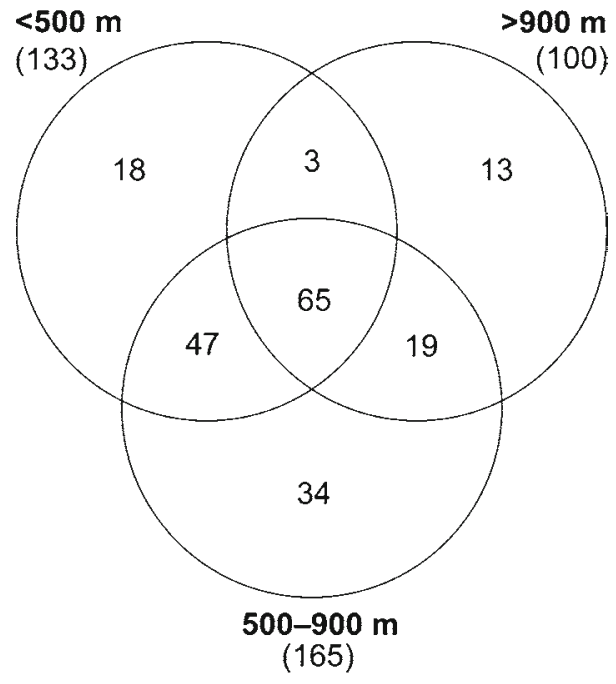

b

Total species pool: 306

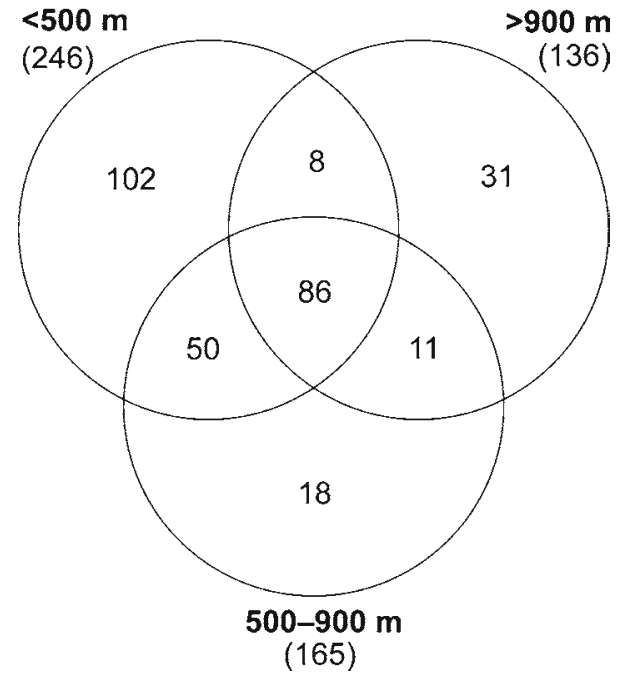

Fig. 6 Partitioning of understory vegetation species richness among the categories of altitude (see Fig. 4). (a) numbers of species in beech-dominated forests; (b) partitioning of species richness of beech-dominated forests $(500-900 \mathrm{~m})$ and other than beech-dominated forests $(<500 \mathrm{~m},>900 \mathrm{~m}$ a.s.1.). The thick circle represents the altitudinal optimum of beech in the studied region. Total species richness per altitudinal bands are in parentheses

The most important mechanisms of the influence of beech on the understory vegetation are the $i$ ) reduction of light availability, ii) accumulation of litter, and iii) root competition for water and soluble nutrients (Sydes and Grime 1981; Kučera 2011). Beech is able to fill the tree-layer canopy completely due to its extraordinary crown growth plasticity (Schröter et al. 2012). In particular a dense closed canopy is formed in monodominant 
beech stands in the centre of the studied altitudinal gradient. The understory light availability during the period of full foliage of beech stands is very low (van Eimern 1984), which suppresses the occurrence of light-demanding understory species which coincide in their vegetative phase with the development of the beech foliage. On the other hand, the admixture of other canopy tree species increases towards the margins of the vertical distribution of beech stands and higher canopy heterogeneity enables better light transmission to the understory (Barbier et al. 2008) and/or faster litter decomposition rates compared to pure beech stands (e.g. Lorenz et al. 2004; Jacob et al. 2010). Various studies have demonstrated that plant species composition and the diversity of the forest understory is affected by the tree species canopy and diversity (van Oijen et al. 2005; Mölder et al. 2008; Wulf and Naaf 2009; Vockenhuber et al. 2011). However, we did not observe statistically significant relationships between the EIV for light and altitude, which may suggest that light does not contribute to the observed species richness distribution along the altitudinal gradient. Therefore, accumulation of leaf litter on the soil surface and belowground competition for water and nutrients seems to be more plausible explanations for the observed relationship.

Beech forest stands are characterized by a large annual production of leaf litter with slower decomposition compared to other deciduous tree species dominating in Central European forests. Undisturbed beech forests thus show a thicker layer of humus than vegetation of other species (Packham et al. 2012). The accumulation and forming of a thick litter layer is unfavourable for the development of understory vegetation as it might form a physical barrier inhibiting germination and emergence of herb layer plants (Mölder et al. 2008; Vockenhuber et al. 2011). In addition to the general influence of climate, soil moisture and temperature regimes on the decomposition rate of deciduous tree litter, the relatively high recalcitrance of beech litter has been attributed to its high $\mathrm{C} / \mathrm{N}$ and lignin/ $\mathrm{N}$ ratio (Jacob et al. 2010).

Competition for available resources (e.g. water) can be another plausible explanation acting jointly with a thick litter layer (Slavíková 1958; Coomes and Grubb 2000; Ellenberg and Leuschner 2010). The intensive transpiration and dense root system of beech result in the effective depletion of soil water (Čermák et al. 1993; Schume et al. 2004). Beech stands show high transpiration rates under both humid and partly dry summer climates in Central Europe (Granier et al. 2000), with transpiration rates varying regionally from 213 to $421 \mathrm{~mm}$ per year (Schipka et al. 2005), making beech a superior competitor for water (Schume et al. 2004). This assumption was supported by the observed relationship between EIV for moisture and altitude and its noticeable similarity with the relationship between species richness and altitude. Although precipitations and soil moisture generally increase along with altitude, our dataset demonstrated an inversely unimodal course for the EIV moisture values. The minimum value was found at approx. $458 \mathrm{~m}$ a.s.1., where beech is considered more abundant and competitive than at lower altitudes. Similar ecological behaviour has been known for other tree species forming temperate and boreal forests (Augusto et al. 2003; Tjoelker et al. 2007; Barbier et al. 2008; Ellenberg and Leuschner 2010).

\section{Species Pool Effect}

We found an obvious shift in species composition along the altitudinal gradient. More specifically, plants usually considered diagnostic and/or dominant species of various 
beech vegetation units (e.g. Moravec et al. 2000; Willner and Grabherr 2007; Jarolímek and Šibík 2008; Matuszkiewicz 2012) were located along the whole altitudinal range, but were concentrated mainly in the central part of the altitudinal gradient. While the herb layer can be enriched by more drought-tolerant species from the adjacent oak and oakhornbeam vegetation types at lower altitudes, more wet-tolerant and/or hygrophilous species may enter from the fir-beech, beech-fir-spruce and spruce forests in the higher altitudinal vegetation zone. There were found 31 montane-zone and colline-zone species which did not occur in the altitudinal optimum of beech (500-900 $\mathrm{m}$ a.s.1.). The penetration of species that have their ecological optimum in adjacent communities, facilitated by a larger diversity of canopy species, can be viewed as a mechanism possibly contributing to the higher species richness observed at both ends of the altitudinal gradient. Transition zones between habitats are predicted to harbour more species than can be found in a habitat centre (ecotone effect according to McCain and Grytnes 2010); the size of the effect is positively associated with differences between habitats.

Indeed, beech-dominated forests occurring on the margins of the altitudinal gradient often form patches in a mosaic with other forest communities. The surrounding oak, oakhornbeam, fir-beech, beech-fir-spruce and spruce forests have generally a larger and/or different species pool than the beech-dominated forest vegetation in the 500-900 m belt. Species richness enhancement in beech forest patches might be explained by the speciespool hypothesis. This claims that the most important determinant of the level of species richness is the number of available species, which in turn depends on speciation, species migration and also on the history and physiography of any particular site (Pärtel et al. 1996). Generally, species richness is positively correlated to the size of the species pool (Pärtel et al. 1996). This theory allows us to explain the shape of the richness-elevation interaction only in the lower parts of the altitudinal gradient, as the set of available species at the upper end of the gradient was lower than in the beech-dominated communities. Moreover, the species pool within beech forests in the three altitudinal zones is ordered in the opposite way to mean species richness which is in contradiction with Pärtel et al. (1996). This finding indicates that the species-pool effect is clearly not the most important mechanism shaping the species richness-altitude relationship. Interspecific competition by beech interacting with the environmental gradients and enabling an admixture of a multiple tree-species canopy appears to be the key to species richness in the studied area.

In addition to the above-mentioned mechanisms, vegetation at lower altitudes is usually more affected by recent migration of alien species (Chytrý et al. 2005). We do not suppose this process to be relevant for the observed species richness patterns, as only a few such species (e.g. Impatiens parviflora, Robinia pseudoacacia) were found in the beech-dominated forests of the studied area.

\section{Conclusions}

The relationship between understory species richness and altitude in beech-dominated vegetation in the Western Carpathians is inversely unimodal. The gradient margins are characterized by higher species richness than the intermediate altitudes. We attributed this pattern to two main factors: competition by overstory beech at its ecological optimum in the central part of the gradient, and the negative effect of thick beech leaf litter and uptake of available resources, mainly water, which prevented the presence of 
many potentially occurring herb and shrub species. A species pool effect from the neighbouring communities also played a role, enriching the lower margins of the altitudinal gradient. To prove the general validity of the observed pattern, further observational studies conducted in homogeneous forest vegetation and substrate conditions are needed.

Acknowledgements We would like to thank Dušan Senko for preparing the map. Our study was supported by grants of the Slovak Grant Agency for Science VEGA (2/0059/11, 2/0027/13) and the long-term research development project no. RVO 67985939 to the Institute of Botany of the Czech Academy of Sciences.

\section{References}

Adams J (2009) Species richness patterns in the diversity of life. Springer-Praxis Publishing, BerlinHeidelberg-New York

Augusto L, Dupouey JL, Ranger, J (2003) Effects of tree species on understory vegetation and environmental conditions in temperate forests. Ann Forest Sci 60:823-831

Austin MP, Cunningham RB, Fleming PN (1984) New approaches to direct gradient analysis using environmental scalars and statistical curve-fitting procedures. Vegetatio 55:11-27

Barbier S, Gosselin F, Belandier P (2008) Influence of tree species on understorey vegetation diversity and mechanisms involved - A critical review for temperate and boreal forests. Forest Ecol Managem 254:1-15

Bhattarai KR, Vetaas OR (2003) Variation in plant species richness of different life form along a subtropical elevation gradient in the Himalayas, east Nepal. Global Ecol Biogeogr 12:327-340

Bhattarai KR, Vetaas OR (2006) Can Rapoport's rule explain tree species richness along the Himalayan elevation gradient, Nepal? Diversity Distrib 12:373-378

Boratyńska K, Boratyński A (1990) Systematyka i geograficzne rozmieszczenie (Systematics and geographical distribution). In Białobok S (ed) Buk zwyczajny. Fagus sylvatica L. Nasze drzewa leśne (European beech. Fagus sylvatica L. Native woody species). Monogr Popularnonaukowe 10:27-73

Brehm G, Colwell RK, Kluge J (2007) The role of environment and mid-domain effect on moth species richness along a tropical elevational gradient. Global Ecol Biogeogr 16:205-219

Brinkmann K, Patzelt A, Dickhoefer U, Schlecht E, Buerkert A (2009) Vegetation patterns and diversity along an altitudinal and a grazing gradient in the Jabal al Akhdar mountain range of northern Oman. $J$ Arid Environm 73:1035-1045

Bruun HH, Moen J, Virtanen R, Grytnes JA, Oksanen L, Angernbjörn A (2006) Effects of altitude and topography on species richness of vascular plants, bryophytes and lichens in alpine communities. J Veg Sci 17:37-46

Chase JM, Leibold MA (2002) Spatial scale dictates the productivity-biodiversity relationship. Nature 416:427-430

Chytrý M, Pyšek P, Tichý L, Knollová I, Danihelka J (2005) Invasions by alien plants in the Czech Republic: a quantitative assessment across habitats. Preslia 77:339-354

Chytrý M, Ermakov N, Danihelka J, Hájek M, Hájková P, Horsák M, Kočí M, Kubešová S, Lustyk P, Otýpková Z, Pelánková B, Valachovič M, Zelený D (2012) High species richness in hemiboreal forests of the northern Russian Altai, southern Sibiria. J Veg Sci 23:605-616

Colwell RK, Hurtt GC (1994) Nonbiological gradients in species richness and a spurious rapoport effect. Amer Naturalist 144:570-595

Colwell RK, Lees DC (2000) The mid-domain effect: geometric constraints on the geography of species richness. Trends Ecol Evol 15:70-76

Colwell RK, Rahbek C, Gotelli NJ (2004) The mid-domain effect and species richness patterns: what have we learned so far? Amer Naturalist 163:E1-E23

Coomes DA, Grubb PJ (2000) Impacts of root competition in forests and woodlands: a theoretical framework and review of experiments. Ecol Monogr 70:171-207

Čermák J, Matyssek R, Kučera J (1993) A cause of a rapid decline of large beech trees on heavy-textured soils after substantial opening of the canopy. Lesnictvi 39:175-183

Dzwonko Z (1990) Ekologia (Ecology). In Białobok S (ed) Buk zwyczajny. Fagus sylvatica L. Nasze drzewa leśne (Fagus sylvatica L. Native woody species). Monogr Popularnonaukowe 10:237-328

Ellenberg H, Leuschner C (2010) Vegetation Mitteleuropas mit den Alpen. Ed. 6. Ulmer Verlag, Stuttgart 
Ellenberg H, Weber HE, Düll R, Wirth W, Werner W, Paulißen D (1992) Zeigerwerte von Pflanzen in Mitteleuropa. Ed. 2. Scripta Geobot 18:1-258

Fekete L, Blattny T (1913) Az erdészeti jelentőségú fák és cserjék elterjedése a Magyar Állam területén (The distribution of forest trees and shrubs in Hungary). Erdészeti Lapok 52:701-720, 743-758

Gömöry D, Kukla J, Schieber B (2011) Taxonómia, fylogenéza a rozšírenie buka v Európe a na Slovensku (Taxonomy, phylogeny and distribution of beech in Europe and in Slovakia). In Barna M, Kulfan J, Bublinec E (eds) Buk a bukové ekosystémy Slovenska (Beech and beech ecosystems of Slovakia). Veda, Bratislava, pp 19-36

Graae BJ, Heskjær VS (1997) A comparison of understorey vegetation between untouched and managed deciduous forest in Denmark. Forest Ecol Managem 96:111-123

Granier A, Biron P, Lemoine D (2000) Water balance, transpiration and canopy conductance in two beech stands. Agric Forest Meteorol 100:291-308

Grau O, Grytnes JA, Birks HJB (2007) A comparison of altitudinal species richness pattern of bryophytes with other plant groups in Nepal, Central Himalaya. J Biogeogr 34:1907-1915

Grytnes JA (2003) Species-richness patterns of vascular plants along seven altitudinal transects in Norway. Ecography 26:291-300

Grytnes JA, Heegaard E, Ihlen PG (2006) Species richness of vascular plants, bryophytes, and lichens along an altitudinal gradient in western Norway. Acta Oecol 29:241-246

Grytnes JA, Beaman JH, Romdal TS, Rahbek C (2008) The mid-domain effect matters: simulation analyses of range-size distribution data from Mount Kinabalu, Borneo. J Biogeogr 35:2138-2142

Härdtle W, von Oheimb G, Friedel A, Meyer H, Westphal C (2004) Relationship between pH-values and nutrient availability in forest soils - the consequences for the use of ecograms in forest ecology. Flora 199:134-142

Jacob M, Viedenz K, Polle A, Thomas FM (2010) Leaf litter decomposition in temperate deciduous forest stands with a decreasing fraction of beech (Fagus sylvatica). Oecologia 164:1083-1094

Jarolímek I, Šibík J (eds) (2008) Diagnostic, constant and dominant species of the higher vegetation units of Slovakia. Veda, Bratislava

Kessler M (2000) Elevational gradients in species richness and endemism of selected plant groups in the central Bolivian Andes. Pl Ecol 149:181-193

Kooijman AM, Cammeraat E (2010) Biological control of beech and hornbeam affects species richness via changes in the organic layer, pH and soil moisture characteristics. Funct Ecol 24:469-477

Körner C (1999) Alpine plant life. Springer Verlag, Berlin, Heidelberg

Kučera A (2011) Vlastnosti půd holých bučin (lesní půdy skupiny typů geobiocénů Fagetum pauper) (Beech forests soil properties (the forest soils in group of types of geobiocoenoses Fagetum pauper)). Dissertation, Mendel University, Brno

Larcher W (2003) Physiological plant ecology: ecophysiology and stress physiology of functional groups. Springer Verlag, Berlin, Heidelberg

Leathwick JR, Burns BR, Clarkson BD (1998) Environmental correlates of tree alpha-diversity in New Zealand primary forests. Ecography 21:235-246

Lobo JM, Castro I, Moreno JC (2001) Spatial and environmental determinants of vascular plant species richness distribution in the Iberian Peninsula and Balearic Islands. Biol J Linn Soc 73:233-253

Lorenz K, Preston CM, Krumrei S, Feger KH (2004) Decomposition of needle/leaf litter from Scots pine, black cherry, common oak and European beech at a conurbation forest site. Eur J Forest Res 123:177188

Marhold K, Hindák F (eds) (1998) Zoznam nižšich a vyšších rastlín flóry Slovenska (Checklist of nonvascular and vascular plants of Slovakia). Veda, Bratislava

Matuszkiewicz W (2012) Przewodnik do oznaczania zbiorowisk roślinnych Polski (Guidebook for determination of plant communities in Poland). Wydawnictwo Naukowe PWN, Warszawa

McCain CM, Grytnes JA (2010) Elevational gradients in species richness. In eLS (Encyclopedia of life sciences). John Wiley \& Sons, Chichester. http:/www.els.net, doi:10.1002/9780470015902.a0022548

Michalko J, Magic D, Berta J, Rybníček K, Rybníčková E (1987) Geobotanical map of C.S.S.R. Slovak Socialist Republic. Text part. Veda, Bratislava

Minchin PR (1989) Montane vegetation of the Mt. Field massif, Tasmania: a test of some hypotheses about properties of community patterns. Vegetatio 83:97-110

Moravec J, Husová M, Chytrý M, Neuhäuslová Z (2000) Přehled vegetace České republiky. Svazek 2. Hygrofilni, mezofilni a xerofilni opadavé lesy (Vegetation survey of the Czech Republic. Volume 2. Hygrophilous, mesophilous and xerophilous deciduous forests). Academia, Praha

Mölder A, Bernhardt-Römermann M, Schmidt W (2008) Herb-layer diversity in deciduous forests: Raised by tree richness or beaten by beech? Forest Ecol Managem 256:272-281 
Mueller-Dombois D, Ellenberg H (1974) Aims and methods of vegetation ecology. John Wiley \& Sons, New York

Oommen MA, Shanker K (2005) Elevational species richness patterns emerge from multiple local mechanisms in Himalayan woody plants. Ecology 86:3039-3047

Packham JR, Thomas PA, Atkinson MD, Degen T (2012) Biological flora of the British Isles: Fagus sylvatica. J Ecol 100:1557-1608

Pärtel M, Zobel M, Zobel K, van der Maarel E (1996) The species pool and its relation to species richness: evidence from Estonian plant communities. Oikos 75:111-117

Rahbek C (1995) The elevational gradient of species richness: a uniform pattern? Ecography 18:200-205

Rahbek C (2005) The role of spatial scale and the perception of large-scale species-richness patterns. Ecol Lett 8:224-239

Sanders NJ, Moss J, Wagner D (2003) Patterns of ant species richness along elevational gradients in an arid ecosystem. Global Ecol Biogeogr 12:93-102

SAS (2009) SAS/STAT_User's Guide, Release 9.1.3 Edition. SAS Institute, Cary, North Carolina

Schipka F, Heimann J, Leuschner C (2005) Regional variation in canopy transpiration of Central European beech forests. Oecologia 143:260-270

Shmida A, Wilson MV (1985) Biological determinants of species diversity. J Biogeogr 12:1-20

Schmidt W (2005) Herb layer species as indicators of biodiversity of managed and unmanaged beech forests. Forest Snow Landscape Res 79:111-125

Schröter M, Härdtle W, von Oheimb G (2012) Crown plasticity and neighbourhood interactions of European beech (Fagus sylvatica L.) in an old-growth forest. Eur J Forest Res 131:787-798

Schume H, Jost G, Hager H (2004) Soil water depletion and recharge patterns in a mixed and pure forest stands of European beech and Norway spruce. $J$ Hydrol 289:258-274

Slavíková J (1958) Einfluss der Buche (Fagus sylvatica L.) als Edifikator auf die Entwicklung der Krautschicht in den Buchenphytozonosen. Preslia 30:19-42

Stevens GC (1992) The elevational gradient in altitudinal range: an extension of Rapoport's latitudinal rule to altitude. Amer Naturalist 140:893-911

Sydes C, Grime JP (1981) Effects of tree leaf litter on herbaceous vegetation in deciduous woodland. $J$ Ecol 69:249-262

ter Braak CJF, Šmilauer P (2002) CANOCO Reference manual and CanoDraw for Windows User's guide. Software for Canonical Community Ordination (version 4.5). Microcomputer Power, Ithaca, New York

Tichý L (2002) JUICE, software for vegetation classification. $J$ Veg Sci 13:451-453

Tinya F, Márialigeti S, Király I, Nément B, Ódor P (2009) The effect of light conditions on herbs, bryophytes and seedlings of temperature mixed forests in Örség, Western Hungary. Pl Ecol 204:69-81

Tjoelker MG, Boratynski A, Bugala W (eds) (2007) Biology and ecology of Norway spruce. Springer, Dordrecht

van Eimern J (1984) Variations of the radiation within and above a beech forest during a phenological year. GeoJournal 8:271-275

van Oijen D, Feijen M, Hommel P, den Ouden J, de Waal R (2005) Effects of tree species composition on within-forest distribution of understorey species. Appl Veg Sci 8:155-166

Vockenhuber EA, Scherber C, Langenbruch C, Meißner M, Seidel D, Tscharntke T (2011) Tree diversity and environmental context predict herb species richness and cover in Germany's largest connected deciduous forest. Perspect Pl Ecol 13:111-119

Willner W, Grabherr G (2007) Die Wälder und Gebüsche Österreichs. Ein Bestimmungswerk mit Tabellen. 1 Textband. Spektrum Akademischer Verlag, Heidelberg

Willner W, Di Pietro R, Bergmeier E (2009) Phytogeographical evidence for post-glacial dispersal limitation of European beech forest species. Ecography 32:1011-1018

Willner W, Moser D, Grabherr G (2004) Alpha and beta diversity in Central European beech forests. Fitosociologia 41(suppl. 1):15-20

Wulf M, Naaf T (2009) Herb layer response to broadleaf tree species with different leaf litter quality and canopy structure in temperate forests. $J$ Veg Sci 20:517-526

Received: 10 May 2012 / Revised: 27 May 2013 / Accepted: 17 June 2013 /

Published online: 17 September 2013 